\title{
Lichen Planus Pigmentosus with Blaschkoid Distribution
}

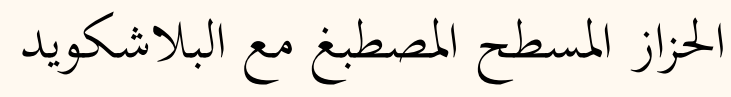

ماريا خوسيه ألونسو-كورال، كريستينا غاريدو-كولمنيرو، آنا المودوفار-ريال، ريكاردو رويز-فيلافيردي
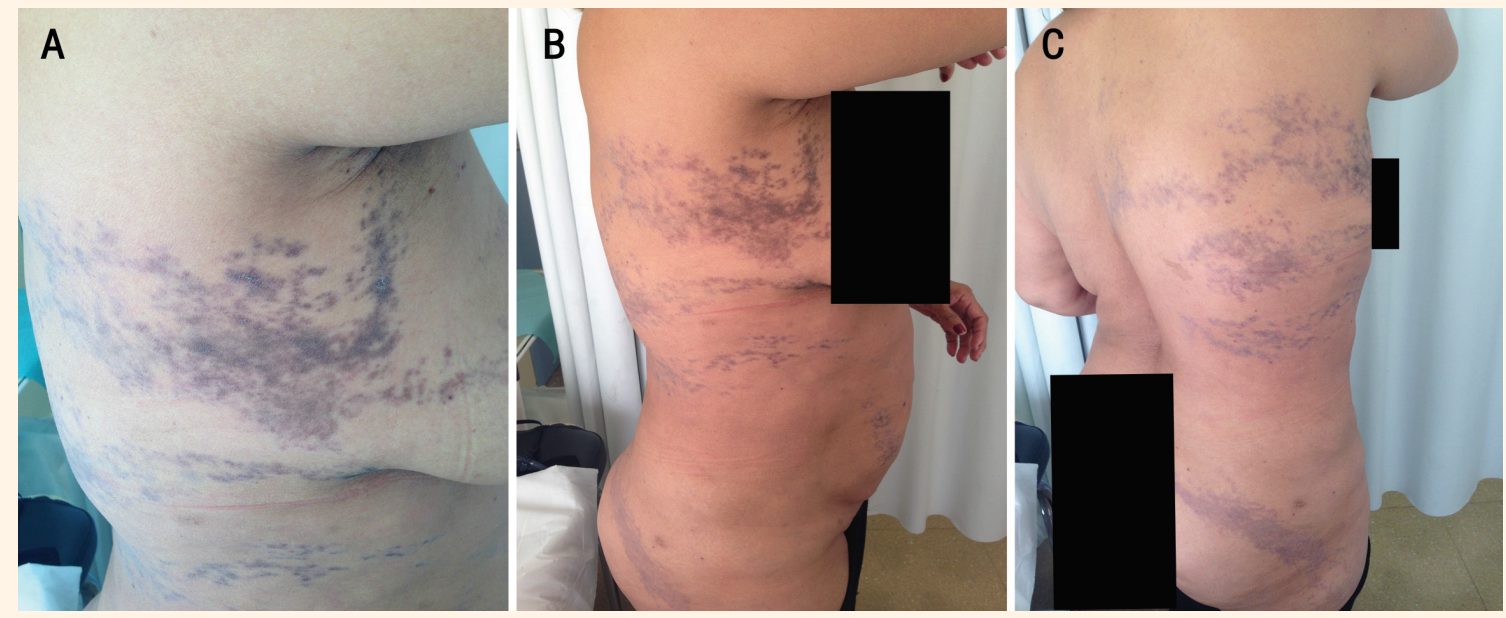

Figure 1A-C: Hyperpigmented brown macules on the (A) right submammary region, (B) right hemithorax, right abdomen and $(\mathbf{C})$ right buttock of a 57-year-old woman.

A

57-YEAR-OLD WOMAN PRESENTED AT A dermatology unit in Granada, Spain, in 2015 with a two-month history of slightly pruritic brown-coloured macular lesions on the trunk and right arm. She was not taking any medications or using cosmetics and had not been exposed to the sun before the onset of the rash. On examination, clearly defined hyperpigmented brown macules were seen on the right submammary region, right hemithorax, right abdomen and right buttock [Figure 1] with an S-shaped appearance, compatible with the pattern of Blaschko lines. Tests for hepatitis B and hepatitis C were negative. A histological examination showed rich lymphocytic infiltrate and melanin incontinence with slight epidermal atrophy and lichenoid reaction with hypergranulosis [Figure 2]. Considering these features, a diagnosis of lichen planus pigmentosus (LPP) with Blaschkoid distribution was proposed. The patient was prescribed topical clobetasol propionate for four weeks. The lesions responded well to the treatment, with significant pigment reduction and improvement of the associated pruritus.

\section{Comment}

Various triggering factors, ranging from viral infections and vaccinations to trauma, have been implicated in the aetiology of lichen planus. ${ }^{1}$ A rare variant of lichen planus, LPP is distinguished by hyperpigmented macules or papules. The histological characteristics of LPP include epidermal atrophy, vacuolar degeneration of the basal cell layer and rich dermal lichenoid infiltrate. ${ }^{2}$ Kanwar et al. suggested that LPP may represent a lichenoid reaction to an unknown agent or stimuli, with regards to the histological concordance between LPP and lichen planus. ${ }^{3}$ The differential diagnosis of LPP includes conditions such as lichen striatus, erythema dyschromicum perstans, incontinentia pigmenti, linear and whorled nevoid hypermelanosis, occupational 


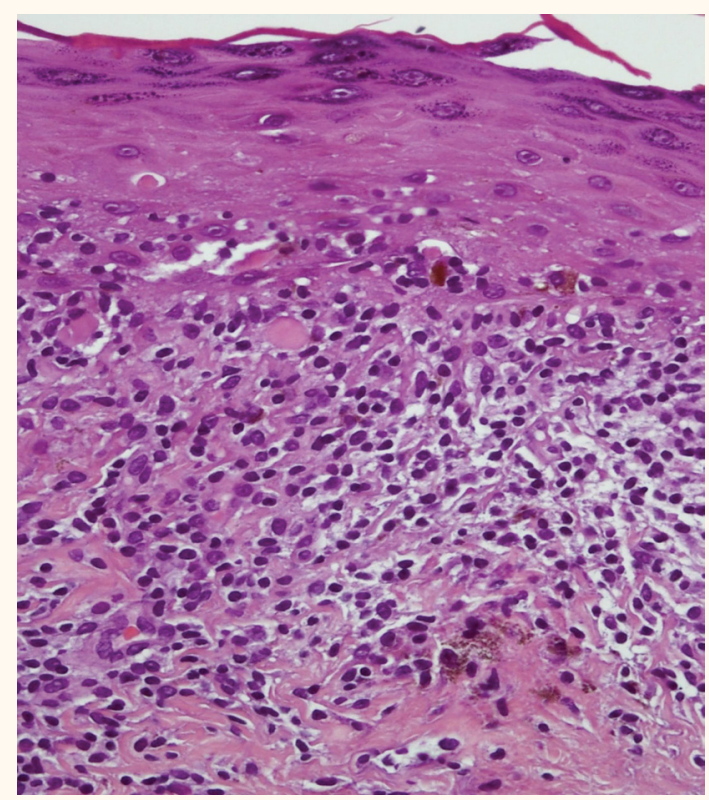

Figure 2: Haematoxylin and eosin stain at x10 magnification showing rich lymphocytic infiltrate and melanin incontinence with light epidermal atrophy and lichenoid reaction with hypergranulosis.

dermatosis with hyperpigmentation and drug-related melanoses. ${ }^{4}$ In the current case, these differential diagnoses were not considered as there was no history of inflammatory processes before the beginning of the hyperpigmentation.

The most frequent variant of LPP is linear, as was observed in the current case, with zosteriform or Blaschkoid LPP being much less common. ${ }^{5}$ The distribution of LPP along the Blaschko lines was first described by Taniguchi et al. in 1993. ${ }^{6}$ Dispersed lesions of classical lichen planus can also occur over the Blaschko lines. ${ }^{7}$ The majority of LPP lesions are usually distributed in areas exposed to the sun; trunk lesions, such as those observed in the present case, are rarely observed. ${ }^{8}$ Both topical and oral treatments for LPP have been used with varying results, including topical steroids, keratolytics, tacrolimus, griseofulvin, prednisone, etretinate and chloroquine., ${ }^{3,4}$

\section{References}

1. Rosenblatt AE, Stein SL. Cutaneous reactions to vaccinations. Clin Dermatol 2015; 33:327-32. doi: 10.1016/j. clindermatol.2014.12.009.

2. Lehman JS, Tollefson MM, Gibson LE. Lichen planus. Int J Dermatol 2009; 48:682-94. doi: 10.1111/j.1365-4632.2009. 04062.x.

3. Kanwar AJ, Dogra S, Handa S, Parsad D, Radotra BD. A study of 124 Indian patients with lichen planus pigmentosus. Clin Exp Dermatol 2003; 28:481-5. doi: 10.1046/j.13652230.2003.01367 x

4. Sharma A, Białynicki-Birula R, Schwartz RA, Janniger CK. Lichen planus: An update and review. Cutis 2012; 90:17-23.

5. Akarsu S, Ilknur T, Özer E, Fetil E. Lichen planus pigmentosus distributed along the lines of Blaschko. Int J Dermatol 2013; 52:253-4. doi: 10.1111/j.1365-4632.2011.04872.x.

6. Taniguchi Y, Minamikawa M, Shimizu M, Ando K, Yamazaki S. Linear lichen planus mimicking creeping eruption. J Dermatol 1993; 20:118-21. doi: 10.1111/j.1346-8138.1993.tb03843.x.

7. Grosshans EM. Acquired blaschkolinear dermatoses. Am J Med Genet 1999; 85:334-7. doi: 10.1002/(SICI)1096-8628(1999 0806)85:4<334::AID-AJMG4>3.0.CO;2-F.

8. Das A, Mishra V, Podder I, Kumar P, Das D, Das NK. Linear lichen planus pigmentosus: A rare entity with an illusory presentation. Pigment Int 2014; 1:100-2. doi: 10.4103/23495847.147048 . 